\title{
Exploration of "Dual system" Talent training Model of German Vocational Education in China
}

\author{
Han Xuejun ${ }^{\mathrm{a}}$, Zhu Yu \\ Dalian Vocational \& Technical College, Liaoning, Dalian \\ a1720413062qq.com, by-dlvtc@163.com
}

Keywords: dual system; talent training model; three docking; Professional quality

\begin{abstract}
The practice of "dual system" personnel training mode in our school and the joint training of GROB Group (Dalian) Co. Ltd. has realized the organic integration of German vocational education model and Chinese traditional higher vocational education system. It reflects the effective integration of Chinese and German cross-cultural, school and corporate cultures.
\end{abstract}

\section{Background}

The "dual system" is a kind of national legislative support in Germany. The school running system is built by the cooperation of the school and the enterprise, that is, enterprise and school jointly undertake the task of training talents, and organize the teaching and post training according to the requirement of the enterprise to the talented person. This model is the main form of vocational and technical education in Germany. It is widely used in German enterprises and has been used by some enterprises in our country in recent years.

In view of the rapid development of enterprises, it is urgent to produce high-quality technical talents engaged in mechanical assembly and electrical installation, to enhance the competitiveness of enterprises and to adapt to the rapid development.

Beginning in the second half of 2012, GORB Group (Dalian) Co. Ltd. and our school after many consultations, in line with the common needs. This paper discusses and implements the pilot training model of "dual system" in German vocational education for reference to the students of our school, and decides to set up a GROB class.

In September 2013, school and GORB Group (Dalian) Co. Ltd. officially held a dual-system talent training cooperation signing ceremony. At the same time, GROB class was set up.

\section{The Concrete Embodiment of the "Dual System" of German Vocational Education in China}

The "dual system" talent training model of Germany is adopted by schools and enterprises together to realize the "three docking" of specialty setup and industry demand, curriculum content and professional standard, teaching process and production process. In the process of training, both the school and the enterprise make clear the training goal, determine the training responsibility, formulate the talent training plan, and carry on the whole process of teaching organization.

\subsection{Joint Determination of Training Objectives-Meeting the Needs of Professional Posts. Training Direction.}

The training orientation of the class is AHK industrial mechanic or AHK industrial electrician. According to their professional divided into mechanical design and manufacturing or electrical automation technology professional two professional directions.

\subsubsection{Double Certificate.}

In addition to the graduation certificate of our school, the class will also obtain the AHK technical certification certificate of the German Chamber of Commerce and Industry. 


\subsubsection{Professional Adjustment.}

In order to ensure the smooth realization of training objectives, considering the needs of enterprises and students, the provincial department of education for consultation and approval, will be selected by different majors for professional adjustment

Schools are responsible for theoretical and public teaching. In order to adapt to the characteristics of dual system teaching, the young teachers should be in charge of dual system course teaching. According to the situation of the class, the school departments and relevant teaching units provide protection from the aspects of teaching plan, teaching execution, teaching implementation, students' rights and interests in school, and so on.

Enterprises are responsible for organizing and implementing the teaching of practical training courses (teaching time including winter vacation and summer vacation) and the additional course of AHK examination, such as AHK examination and certification. To provide students with complete labor insurance supplies, safety training, supplementary sickness and accident insurance, student transportation, a certain living allowance and internship allowance, and enjoy the same holidays as regular employees with less than five years of service in the enterprise.

\subsection{To Jointly Formulate a Talent Training Plan-to Realize the Docking of Course Teaching and Practical Training in Production.}

\subsubsection{Training Methods.}

Adopting the "dual system" personnel training mode, the school and enterprises work together to develop a talent training plan, sharing training information. In the three-year teaching cycle, one and a half years in school, complete the normal professional teaching (professional theory teaching tasks and public cultural teaching tasks); more than half of the time in enterprises. By the enterprise responsible for the completion of German AHK vocational skills qualification training (practical teaching task). In particular, students in this class will carry out AHK vocational qualification skills training in enterprises during winter and summer vacation, according to the management of employees and the working hours of enterprises.

Table 1 Dual system training mode

\begin{tabular}{|c|c|c|c|c|c|c|}
\hline Class & $\begin{array}{c}\text { First } \\
\text { semester }\end{array}$ & $\begin{array}{c}\text { second } \\
\text { semester }\end{array}$ & $\begin{array}{c}\text { Third } \\
\text { semester }\end{array}$ & $\begin{array}{c}\text { Fourth } \\
\text { semester }\end{array}$ & $\begin{array}{c}\text { Fifth } \\
\text { semester }\end{array}$ & $\begin{array}{c}\text { Sixth } \\
\text { semester }\end{array}$ \\
\hline $\begin{array}{l}\text { Industrial } \\
\text { mechanic } \\
\text { direction }\end{array}$ & \multirow{2}{*}{$\begin{array}{c}\text { 3-day } \\
\text { school } \\
\text { 2-days } \\
\text { enterprise }\end{array}$} & $\begin{array}{c}\text { 2-days } \\
\text { school } \\
\text { 3-days } \\
\text { enterprise }\end{array}$ & $\begin{array}{c}\text { 2-days } \\
\text { school } \\
\text { 3-days } \\
\text { enterprise }\end{array}$ & $\begin{array}{c}\text { 2-days } \\
\text { school } \\
\text { 3-days } \\
\text { enterprise }\end{array}$ & $\begin{array}{c}\text { 1-day } \\
\text { school } \\
\text { 4-days } \\
\text { enterprise }\end{array}$ & $\begin{array}{l}\text { 5-days } \\
\text { enterprise }\end{array}$ \\
\hline $\begin{array}{l}\text { Direction of } \\
\text { industrial } \\
\text { electrician }\end{array}$ & & $\begin{array}{l}\text { 3-days } \\
\text { school } \\
\text { 2-days } \\
\text { enterprise }\end{array}$ & $\begin{array}{l}\text { 2-days } \\
\text { school } \\
\text { 3-days } \\
\text { enterprise }\end{array}$ & $\begin{array}{c}\text { 2-days } \\
\text { school } \\
\text { 3-days } \\
\text { enterprise }\end{array}$ & $\begin{array}{c}\text { 1-day } \\
\text { school } \\
\text { 4-days } \\
\text { enterprise }\end{array}$ & $\begin{array}{c}\text { 5-days } \\
\text { enterprise }\end{array}$ \\
\hline
\end{tabular}

\subsubsection{Professional Curriculum Adjustment.}

In accordance with the dual system talent training program jointly formulated by both schools and enterprises, the school should reform the teaching of traditional professional teaching courses, and adjust the relevant professional courses in accordance with the requirements of enterprise AHK vocational skills qualification training (practical teaching tasks). Advance some professional courses (E.g. cutting tools, machine tools, etc.), and delay the implementation of some public courses.

\subsubsection{Public Curriculum Reform.}

In accordance with the dual-system talent training program jointly formulated by both the school and the enterprise, the school has carried out teaching reform on some public courses (Ideological and political lessons) in order to meet the needs of the teaching time arrangement of the major. The 
former classroom teaching has been changed into teacher-guided teaching, and students use public resources to learn after class to complete the goal of public curriculum teaching.

\subsection{Implement and Evaluate the Teaching Organization Jointly-Realize the Connection between Teaching Resources and Teaching Management.}

Because of the change of dual system personnel training mode, the service content, service form and management system must change accordingly. Both schools and enterprises do their best to ensure the smooth implementation of the teaching organization.

\subsubsection{The School Teaching Organization.}

The school is responsible for the theory teaching and the public teaching. In order to adapt to the characteristics of dual system teaching, the young teachers should be in charge of dual system course teaching. According to the situation of the class, the school departments and other departments give thoughtful and meticulous arrangements from the aspects of teaching plan, teaching execution, teaching implementation and so on.

\subsubsection{Professional Education.}

In order to ensure the smooth realization of the training goal of dual system talents, to solve the problem that students do not know enough about their major, and to deepen their understanding of the characteristics of factory processing, special professional education has been organized. For the rapid entry into the workplace environment and follow-up professional courses to do a good job.

\subsubsection{Enterprise Teaching Organization.}

The enterprise training center is responsible for all practical teaching of this class. The company is equipped with 4 instructors with rich experience in production practice, full set of German manufacturing equipment, according to AHK vocational qualification training standards. The training effect of students was obviously higher than that of professional classes of the same grade.

\subsubsection{Evaluation of Learning Effects.}

Schools and enterprises jointly manage and evaluate the class. The school is responsible for teaching management and theoretical teaching evaluation, and the enterprise is responsible for practical teaching evaluation according to AHK vocational qualification training standard. The results of the whole examination and evaluation should be incorporated into the school achievement management system in order to ensure that students' higher vocational education and vocational qualification education can be completed at the same time.

\subsubsection{Contact Communication System.}

The two sides of the school and enterprise set up contact group to adjust the arrangement of the teaching plan, the problems in the course of teaching implementation, the students' learning state and the thought dynamic and timely communication. The school specially organized 2 symposiums, aimed at the student's study process and the life link carried on the exchange. Timely send staff to participate in enterprise teaching research and communication work.

\subsection{Student Management and Class Culture Construction-To Serve the Needs of the Cultivation of Comprehensive Quality and Ability.}

\subsubsection{Students' Rights and Interests.}

Students start from school and are managed by both sides of the school and business. Students are both school students and enterprise quasi employees. But the student's main identity is a student. This is a very clear identification between the two sides (one of the main differences with the German Dual System). The enterprise provides a certain monthly allowance and internship allowance for the students. School and enterprise come and go bus, reimburse student accommodation expenses, supplement various kinds of insurance, according to the management of the official staff of the enterprise under five years of working age. In the preliminary calculation, 
the enterprise has to invest more than 10 thousand yuan each year for each student directly (excluding the practice of training teaching).

\subsubsection{Professional Quality.}

Due to the need of dual system, students alternate between the school and the enterprise, receiving two completely different quality education environment, but more to accept the corporate culture and business atmosphere. Students in the enterprise according to enterprise management, enterprises require employees to work consciously, conscious learning initiative, since the implementation of the class, students work initiative, sense of responsibility, communication skills and other professional quality has been significantly improved.

\subsubsection{Class Culture.}

Due to the dual system, the class is much worse than the students in the extracurricular activities. To this end, with the enterprise agreement, the school must participate in large-scale student activities. At the same time, special arrangements for the professional director as the class mentor, and equipped with a strong instructor as class teacher. On the one hand, the system guarantees, on the other hand, the class absorbs more cultural soil from the enterprise to create a stronger class culture.

\subsubsection{Humanistic Concern.}

Due to the students in the school study time 8 hours per day, corporate internship time all day, basically full load operation. Students have passion but also tired, but the class also got more humanistic care. The annual meeting takes the students as prospective employees, and the school also organizes students to spend the New Year's Day with them during the winter holiday.

\subsubsection{Winter and Summer Vacation Management.}

According to the agreement, students do not have a holiday during the summer and winter vacation, and they are included in the management of the enterprise. According to the AHK vocational qualification training standard, the enterprise continues to carry out practical training teaching. The school student management department and the logistic management department have made thoughtful and meticulous arrangements to ensure the good study in the enterprise and the rest in the school during the winter and summer vacation.

\section{Some Thoughts on the "Dual System" in China}

\subsection{Serving the Needs of Enterprises and Exploring the New Mode of Training Talents with Dual System in China.}

Higher vocational school is not only vocational education itself, but also the duty and responsibility of providing talents in the region. This kind of cooperation not only reflects the school's idea of actively serving the enterprise in order to meet the needs of the enterprise, but also reflects the school's courage to explore a new mode of training talents in higher vocational education, which is more in line with the needs of the new situation of higher vocational education. It is a new subject to the education and teaching of schools from the aspects of cultivation and management of dual subjects, and the cooperative dual system is not a complete German dual system, but a Chinese dual system.

\subsection{The Integration of School Management and Corporate Culture Needs the Joint Efforts of Both Sides.}

From the school management level, there is a series of management rules and regulations, and the enterprise has a unique corporate culture and enterprise management system, there are inevitable contradictions and conflicts between the two, whether from the cultural concept, From the point of view of the concept of region and the requirement of cultivation, it is inevitable to exist. From the establishment and operation of GROB Group, the same is true. But the key is how to deal with and 
solve the problems that arise. For example, theory teaching and practice teaching time arrangement and so on. As a system of communication and exchange between the two sides has been established from the beginning, discussions will be held at any time on the issues that arise; in addition, senior leaders of the two sides will also listen to work reports at any time. Arrange the related matters of the class. Fully ensure the current good operation state.

\subsection{The Beneficial Practice Exploration of the Pilot Work of Modern Apprenticeship System.}

In accordance with the needs of enterprises, the joint enrollment of schools and enterprises should be carried out, the modern apprenticeship system should be established, and the students should be doubly educated and managed. When students study in school, they are both students in school and apprentices in enterprises. They form the "three docking" of specialty setup and industry demand, curriculum content and professional standard, teaching process and production process. In order to improve the pertinence and effectiveness of skilled personnel training. At the time of graduation (the end of apprenticeship), the system of "double certificate" (qualification certificate of qualification) and the system of accumulation of technical skills of modern apprenticeship system should be implemented, and the problem of lack of high-quality skilled personnel in cooperative enterprises should be solved.

\section{Acknowledgement}

Researching results of 2014 subject "A study on the Chinese pattern of dual system personnel training in German Vocational Education" of the 12th Five-Year Plan of Liaoning Province Education Science (Project Number: JG14EB064, Topic Moderator: Xuejun Han).

\section{References}

[1] Li Guoyan, Gai Fu, Zhu Yu and Meng Qingyun. The Construction and practice of the course system of "double body and one Wing" for Modern Apprenticeship Specialty. China occupation technology education. 2016(23):75-79

[2] Yu Xiaofei. A study on the Innovation of the Mode of "Integration of Industry and Education" in Vocational Education. Management manager.2015

[3] Su Chengbai, Wang Sufeng, Shi Huizhong. Discussion on the Application of Modern Apprenticeship system in the Construction of skilled talents in Petroleum Enterprises. Oil education. 2014

[4] Yang Yongjian, Cao Shuai, Zhu Ming. Research on the training of outstanding technicians based on the mode of "modern apprenticeship". Research on composition Teaching. 2016

[5] Yang Zhenghong. Reflections on the implementation of Modern Apprenticeship system for Railway Power supply Technology Specialty in our University. Modern vocational education. 2017

[6] Zhu Yu. A Study on the Training Model of "Dual system" based on the Mechanism Specialty. Advances in Social Science, Education and Humanities Research. 2017 